\section{RIEHTMANN}

P U B I I S H I II G
Research Article

(C) 2019 Emil Gochaevich Adleiba and Vasil Timerjanovich Sakaev. This is an open access article licensed under the Creative Commons Attribution-NonCommercial-NoDerivs License (http://creativecommons.org/licenses/by-nc-nd/3.0/).

\title{
Cultural Diplomacy of France: Essence, Main Directions and Tools
}

\author{
Emil Gochaevich Adleiba
}

Vasil Timerjanovich Sakaev*

Kazan Federal University

${ }^{*}$ Corresponding Author

Doi: $10.36941 /$ jesr-2019-0024

\begin{abstract}
The article is devoted to the study of "cultural diplomacy" of France in recent history. The relevance of the topic is conditioned by the fact that states use new, non-leverage levers of influence more and more, striving to spread their values and culture in the world to expand and strengthen their presence in the international arena. The French Republic, in order to revive its former greatness, has accelerated the activities of its institutions over the past decades, which can be interpreted as the manifestations of "soft power" in general, and "cultural diplomacy" in particular. The increase of the French language, culture and history status among the population of Europe, America, Africa and the Middle East is becoming an increasing priority task of the state foreign policy. This, in particular, is evidenced by the statements of the French leadership, as well as the reforms carried out in internal structures to increase the effectiveness of its "cultural diplomacy" concept implementation. The authors of the article concluded that over the past ten years, France has not only stepped up and renewed its cultural and partnership relations around the world, but also opened up new opportunities for the dissemination of information and cooperation, adapting to the diverse expectations of the audience, taking into account, first of all, the factors of multilateral diplomacy and interculturalism. This, in its turn, makes it possible to expect the increase of France foreign policy potential in the international arena. The obtained results are consistent with the conclusions of a number of researchers and expand the existing ideas about the nature, the application of "cultural diplomacy" approaches and the specifics of its influence in the world. The reliability of the study is based on a wide range of published materials, and the obtained results make a significant contribution to knowledge expansion about this problem. At the end of the article, on the basis of France experience study, they determined the potential opportunities for the development of "cultural diplomacy" of Russia.
\end{abstract}

Keywords: cultural diplomacy, France, culture, impact, security, national interests, language, power, foreign policy, Africa

\section{Introduction}

At present, more and more countries begin to use new, non-power levers of influence, including the spread of their values and culture in the world, to expand and strengthen their presence in the international arena. This phenomenon is called "cultural diplomacy." The French Republic, in order to revive its former greatness, has also significantly intensified the activities of its institutions over the past decades, whose work can be interpreted as the manifestations of "soft power" in general, and "cultural diplomacy" in particular.

Although the foreign policy of France has already become the subject of research in many Russian and foreign works, nevertheless, the issue of the foreign cultural policy of France was not covered sufficiently in the scientific literature. This is due, inter alia, to the restructuring of its activities in the indicated direction that has taken place in recent years. 
Among the studies devoted to this problem, the number of Russian writers affecting the foreign policy of France and its cultural influence can be noted, such as Kudryavtsev A.K. (Kudryavtsev, 2014), Rubinsky Yu.I. (Rubinskij, 2007), Trofimova O.E. (Trofimova, 2009) and others.

A number of authors should be singled out in foreign historiography, who made a significant contribution to the study of the foreign policy issues of the French Republic, such as Jacques Toby (Thobie, 1977), Martin Evans (Evans, 2002; Evans, 2004), and Dominic Moisi (Moïsi, 2008). These researchers examined, among other things, the problems and achievements of French foreign policy, analyzed foreign cultural policy in relation to the countries of the Arab and African world. French scholars noted the particularities of the French approach to "cultural diplomacy", especially emphasizing the role of language in this policy.

Of course, speaking of "cultural diplomacy", one cannot fail to mention the work of Joseph Nye, the founder of "soft power" concept (Nye Jr, 2004). The concept of "cultural diplomacy" was finally formed on the basis of his work, which became the subject of our study. At the same time, he clearly draws a red line in his last work separating "soft power" from "hard power" (Nye, 2019).

\section{Methods}

The research methodology is based on a structural-functional approach, historical and logical methods that allow to determine the stages and patterns of "cultural diplomacy" of France development, to determine its features and implementation specifics.

\section{Results}

With the development of interstate relations and, accordingly, the emergence of new spheres of influence, the phenomenon of "cultural diplomacy" has become an important tool for diplomacy, which serves to advance the interests of the state, and also helps to implement the goals of comprehensive cooperation between entire nations and countries.

The term "cultural diplomacy" appeared in the middle of the 20th century, when the American Researcher F. Barghorn explained this phenomenon as "the manipulation of cultural materials and personnel for propaganda purposes" (Barghoorn, 1960). At the same time, "cultural diplomacy" is the part of the "soft power" policy, which is based on the exchange of cultural components (art, traditions, language, information, etc.) (Lenczowski, 2008).

In our opinion, we can speak of a systematic approach to the development of cultural institutions after the Franco-Prussian war (1870-1871). Then, France, which defeated in the war with Germany, made an attempt to transform the role of culture in the context of diplomacy. France has transformed the approach to its foreign policy, realizing that military revenge is not possible yet. In 1883, they established the first cultural institute in history, whose landmark was aimed at working abroad. This institute was named "Alliance Francaise", which set the task of French language and literature popularization abroad. Having established this institute, private individuals began to open French language courses all over the world and publish French-language literature. Ultimately, thanks to it, France managed to establish the organization of French-speaking countries in 1970 Francophonie. Since 1970, it has united 58 states. French is the official language of communication for more than 275 million people. In addition, according to INED, about 750 million people will speak French in Africa by 2050. The goal of French cultural institutions is to promote Francophonie. Naturally, this "cultural" influence affects the current position of France in the world, since the common system of values and worldviews is also transmitted through language.

Besides, French is an international language used by international organizations such as the UN or the International Olympic Committee.

However, after World War II, French, which has been the main language of diplomatic communication for centuries, has been supplanted by English. The American cultural expansion was added to this, which greatly affected the national pride of the French and generated the zeal for their cultural characteristics protection.

We can assume that Francophonie, in the conditions of France position weakening on the 
world stage has become a "new horizon" for the country after the Second World War and the collapse of the colonial system. Schematically, the essence of this new approach was the following one: the mainstay is the state; the goal is to maintain the position of France in the new international "concert"; the means are represented by the creation of a new, unique, universal and diplomatic cultural network. The era of digitalization has also given a new impetus to the development of this approach.

In contrast to the strategies pursued by other states, the specificity of France foreign cultural activity is conditioned by the fact that executive structures have different statuses (public or private) and different tasks.

Thus, the Ministry of Foreign Affairs formulated the following foreign policy goals, including the tasks of "cultural diplomacy":

- The protection of population and French citizens abroad in conditions of instability and tension;

- The protection of France interests in terms of increasing competition and the loss of speed among multilateral institutions;

- The ability to defend own views and strengthen own image in the context of the information war and the economy.

To achieve these goals, France has an extensive network of diplomatic and consular offices in more than 160 countries.

Speaking about the value structure of French "cultural diplomacy", we can, first of all, highlight the image of France as the birthplace of the idea of human rights. At the same time, you need to understand that this image is perceived differently, for example, in European countries and former colonial countries, so this image maintaining and strengthening becomes a goal for France.

As you know, the report of the "SoftPower30" commission was presented in Davos (2017), which, based on an analysis of a number of factors (culture, cooking, language, entrepreneurship, education, art, foreign policy, peacefulness and attractiveness), put France first in the list of the most influential countries in terms of "soft power" (Gray, 2017). The authors of the report considered that France has more opportunities to influence the world community than the United States.

Of course, at present France has such important cultural values as language and art. Paris plays the role of a leading cultural center of the world. The headquarters of several influential IGOs, such as UNESCO, OECD, the International Chamber of Commerce and others, are also located here. The republic also has one of the largest networks of cultural centers in the world (154 cooperation departments, 124 French institutes, more than 6,000 employees worldwide, 800 Unions and 495 French lyceums), which undoubtedly gives a universal character and strengthens the capabilities of the French diplomacy. However, the costs of its maintenance amount to about 750 million euros per year, which is a very serious burden for the country budget.

French cultural institutions and services carry out the following tasks in their activities:

- Distribution of culture abroad through the works of French artists and writers (more than 26,000 events a year abroad);

- The creation of sustainable networks between politicians as well as between cultural figures.

In order to develop the potential of its "cultural diplomacy" France pursues a special policy of cooperation with the countries that make the part of the so-called "Zone of Priority Solidarity" (ZPS). In particular, the French Ministry of Culture has developed a special program "Africa and the Caribbean," which is aimed at access support to new markets, as well as on economic culture development to spread French industry.

In order to help spread its culture, the French Ministry of Culture also provides additional 150 million euros to support French media abroad, including RTF and France 24. Over the past decades, the French media have adopted a common strategy to revitalize and modernize international broadcasting. To this end, the state agency France Monde was reorganized with the aim of French culture, language, as well as the position and views of France distribution on different pressing problems, through television and radio broadcasts. 
The main French "locators" today are the following ones:

- France 24, the news channel created in 2006 and performing broadcast on three separate channels in French, English and Arabic with the following motto: "Freedom, Equality, News".

- RFI, multilingual international information radio (12 foreign representative offices), which has existed since 1983.

- Monte Carlo Dualia (formerly Radio Monte Carlo Middle East, created in 1972 and transformed in 2006), the French radio in Arabic, which acts as the "Radio of Liberty in Arabic".

In 2018, the total audience of France Monde holding amounted to more than 150 million people.

Thus, the scale of the activity is impressive, but the costs are enormous. Thus, there is the issue of the cultural network development effectiveness, its structuring and rationalization. For this reason, the reform of the network organization was launched in 2008, which provides for the creation of a single institution in each country under the leadership of an embassy adviser on cultural issues with financial independence. This new structure should carry out several tasks at the same time, and is also intended to give a unique image to the network arrangement and provide more management flexibility in practice.

\section{Discussion}

As we have indicated, in spite of the obvious successes, the effectiveness issue is important concerning the current "cultural diplomacy" tools of France. So, M. Fushev in his book "European Republic. Historical and geographical contours" indicates the following: "France, although perceived as a state that promotes intellectual emulation, has no longer represented the ideas in the European arena for a decade" (Fushe, 1999). It is difficult to disagree with this statement. However, one cannot fail to admit that the "soft power" of France is not fully involved yet in the process of its strategy implementation and there is considerable potential for its development by innovative approach creation.

One of these development areas should be the EU space. So, there is the restructuring of the French centers, the increase of cultural presence financing within the European Union. According to official reports, now "the first policy circle of French-speaking countries is the zone of the European Union countries" (Kessler, 1999). In particular, the following goals were voiced during the EU presidency: compulsory teaching of two foreign languages before graduating from high school; assistance in the development of foreign language teaching; systematic development of bilingual education; the French language support along with English as the working language of the EU, taking into account the accession of new countries. Undoubtedly, with the upcoming Brexit, the role of the French language will increase even more.

Another priority aspect of "cultural" diplomacy is university education. Currently, foreign students are an important source of income for France (in 2017, 10\% of income from higher education came from foreign students). Former Minister of Foreign Affairs of France Laurent Fabius announced the following goal: to attract 700,000 foreign students (nowadays, there are about 300,000 students) and the main task is to get out of the traditional "French basin" (former French colonies) and attract a new audience.

Comparing the successes of French "cultural diplomacy" with the potential capabilities of Russia, we can indicate that our country also has the potential of influence inherited from the USSR abroad, for example, in Arab countries (Kolesnikov et al., 2017), which must be developed systematically. In the post-Soviet space, the potential influence of Russia, is associated first of all with the presence of diasporas and the prevalence of the Russian language (Sakaev, 2016) and it should also be supported purposefully. In addition, we see an active policy on university education internationalization and foreign student attraction, where certain successes have already been outlined (Khayrutdinov et al., 2017). Moreover, it is very important not to cross the "red line" and not to discredit the potential of "cultural diplomacy" turning it into "Hard power" potential, according to Joseph Nye warning (Nye, 2019). 


\section{Conclusions}

Undoubtedly, "cultural diplomacy" is an important component of the state foreign policy. It falls within the competence of the main department for globalization, development and partnership of the Ministry of Foreign Affairs, is implemented through a large network of representative offices abroad and is focused on the solution of two important tasks: the development of high-priority relations and France and its culture attractiveness increase.

It is ecessary to admit that the tools of classical diplomacy alone are not enough currently. Innovative solutions are needed, and the French leadership, including the President E. Macron, is actively seeking for their identification. So, the most effective factor of "soft power" is the appeal to a multilateral approach in international relations. Over the past ten years, France has not only intensified its cultural and partnership relations around the world, but also opened up new opportunities for the dissemination of information and cooperation, adapting to the diverse expectations of the audience, taking into account the cross-cultural factor.

\section{Summary}

Thus, France has significantly intensified its cultural presence in recent decades, and has begun to use the leverage of "soft power" actively to form a more attractive image of its culture, language, and art purposefully. The use of such tools as France Media, France Museums agencies, UNESCO international institutes, Francophonies, holding mass sports and cultural festivals, as well as the cardinal revision of approaches to their foreign cultural policy development, demonstrates the comprehensive approach and the potential for France cultural influence spread. The French language is still important, but its distribution now, as a rule, goes to the background, giving way to the actions aimed primarily at the provision of France presence, its culture and values in the international arena.

\section{Acknowledgements}

The work is performed according to the Russian Government Program of Competitive Growth of Kazan Federal University.

\section{References}

Barghoorn, F. C. (1960). The Soviet Cultural Offensive. The role of Cultural Diplomacy in Soviet Foreign Policy. Princeton.

Evans, M. (2002). Propaganda and Visions of Empire in France. Palgrave.

Evans, M. (2004). Empire and Culture. TheFrenchExperience, 1830-1940, Palgrave.

Fushe, M. (1999). Evropejskayarespublika. Istoricheskie i geograficheskiekontury. Moscow, Mezdunarodnyeotnosheniya, (in Russian).

Gray, A. (2017, July). France becomes the world no 1 for soft power. In World Economic Forum (Vol. 27).

Kessler, M. C. (1999). La politique étrangère de la France: acteurs et processus. Paris: Presses de sciences Po.

Khayrutdinov, R. R., Shakirova, A. A.,,Ayupova, L. I.,, Gizyatova, L. A. (2017). Globalization of culture and higher education by means of academic mobility. European Research Studies Journal, 20, 377-385.

Kolesnikov, P. M., Sakaev, V. T.,,Safin, M. F., Moharychev, K. Y. (2017). The future of Russian-Arab relations in the context of the political crisis in the middle East. Man in India, 97(9), 109-119.

Kudryavtsev, A. K. (2014). Frantsuzskiesotsialisty u vlasti: v poiskakhreshenijstrukturnykh problem. Moscow, IMEMO RAS. (in Russian).

Lenczowski, J. (2008). Cultural diplomacy, political influence, and integrated strategy. Strategic influence: Public diplomacy, counterpropaganda, and political warfare.

Moïsi, D. (2008). La géopolitique de l'émotion: Comment les cultures de peur, d'humiliation et d'espoirfaçonnent le monde. Flammarion, Paris [Electronic source] URL: https://www.lemonde.fr/livres/article/2008/11/26/lageopolitique-de-I-emotion-de-dominique-moisi_1123339_3260.html (date of access: 19.04.2019).

Nye Jr, J. S. (2004). Soft power and American foreign policy. Political Science Quarterly, 119(2), 255-270.

Nye Jr, J. S. (2004). Soft Power: The Means to Success in World Politics. Public affairs. 
Nye, J. S. (2019). Soft power and public diplomacy revisited. The Hague Journal of Diplomacy, 14(1-2), 7-20.

Rubinskij, YU. I. (2007). Frantsiya: poisknovykhputej. Moscow, Ves' mir (in Russian).

Sakaev, V. T. (2016). The political demography of the eurasian economic union. Journal of Economics and Economic Education Research, 17(2), 169-177.

Thobie, J. (1977). Intérêts et impérialisme français dans l'Empire ottoman: 1895-1914(Vol. 4). La Documentation Française.

Trofimova, O. E. (2009). Musul'mane i islam v ZapadnojEvrope. Mirovayaehkonomika $i$ mezhdunarodnyeotnosheniya, 10, 52-62 (in Russian). 